Afrem - 圆

\title{
Rевевсн автіск: Effectiveness of NAIP in strengths of NAIP with special reference to livestock based ifs interventions among the tribal beneficiaries
}

\author{
R.K. DAMOR, K.L. DANGI, H.K. JAIN AND R.L. KHATIK
}

Article Chronicle: Received :

14.02.2017;

Revised :

12.03.2017;

Accepted :

25.03.2017

KeY WoRds:

NAIP, Beneficiaries, Livestock based IFS, Strengths, Interventions

Author for correspondence :

\section{R.K. DAMOR}

Department of

Extension Education,

RCA Campus, Surajpal,

UDAIPUR (RAJASTHAN)

INDIA

Email:ramlalkhatik89@

gmail.com

See end of the article for authors' affiliations
SUMMARY : Six year ambitious agricultural research Programme was launched in India on $6^{\text {th }}$ July, 2006, which is known as National Agricultural Innovation Project (NAIP), the project focused on innovations in agricultural technology. Four districts of Rajasthan viz., Udaipur, Banswara, Dungarpur and Sirohi figure prominently as the disadvantaged districts identified by the planning commission, based on income, tribal population, their resources, state of agriculture, etc. Keeping in view the challenges of food and nutritional security, National Agricultural Innovation consortia project was initiated by the ICAR in MPUAT, Udaipur. The NAIP was implemented in four districts of southern Rajasthan state viz., Banswara, Dungarpur, Sirohi and Udaipur. Two clusters of Dungarpur district were selected for the present study. These were (a) Faloj and (b) Bichhiwara. Total 10 villages out of 15 villages (under NAIP) were selected proportionately on random basis for inclusion in the study. Total size of sample was of 104 respondents. It was found the strengths that $95(91.35 \%)$ of the farmers were of their face values expressing strengths of NAIP with moderate extent. Negligible respondents 5 (4.81 $\%)$ and $4(3.84 \%)$ could be observed falling under high and low strengths of NAIP, respectively. Furthermore, data clearly show strong aspects of NAIP with special reference to livestock based IFS were "green fodder production", "milk production", "use of agricultural implements", "feeding pattern of animals", "artificial insemination" and "use of processing equipments" as per the perception of tribal beneficiaries. These were ranked from 1 to 6 in sequential order in the hierarchy of 14 aspects of strengths. On the other hand, the aspects viz., saving, use of biogas plants, fish production, use of mangers, water management and composting / vermin-composting were perceived by the farmers as comparatively less strong for deriving benefits out of NAIP.

How to cite this article : Damor, R.K., Dangi, K.L., Jain, H.K. and Khatik, R.L. (2017). Effectiveness of NAIP in strengths of NAIP with special reference to livestock based ifs interventions among the tribal beneficiaries. Agric. Update, 12(2): 229-232; DOI : 10.15740/HAS/AU/12.2/229-232. 